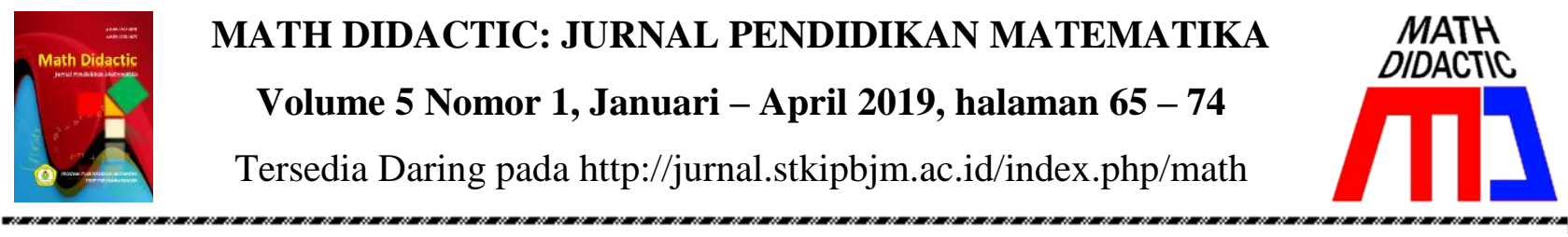

\title{
PENGUASAAN KONSEP ALJABAR DAN ARITMATIKA UNTUK MENYELESAIKAN SOAL-SOAL FISIKA DASAR
}

\section{MASTERY OF ALJABAR AND ARITMATIC CONCEPTS TO COMPLETE BASIC PHYSICAL PROBLEMS}

\author{
Sitti Rahmasari \\ Universitas Islam Negeri Antasari \\ sitti.rahmasari@uin-antasari.ac.id
}

\begin{abstract}
Abstrak: Matematika dan fisika terjalin dengan sangat erat karena konsep matematika digunakan dalam fisika. Fisika adalah bagian dari ilmu sains yang mempelajari perilaku alam melalui pengamatan secara eksperimental dan pegukuran secara kuantitatif. Fisika menggunakan bahasa matematika untuk memodelkan gejala alam ke dalam persamaan matematis, sehingga di dalam mempelajari fisika, diperlukan kemampuan matematis sebagai kemampuan awal peserta didik dalam menyelesaikan permasalahan fisika. Penelitian ini menggunakan pendekatan kuantitatif dengan metode deskriptif korelasi untuk menganalisis konsep-konsep matematika yang diperlukan dalam menyelesaikan soal fisikadasar materi listrik statis pada program studi Tadris Fisika UIN Antasari. Hasil penelitian menujukkan bahwa terdapat korelasi yang tinggi antara penguasaan konsep aritmatika dan aljabar dengan kemampuan mahasiswa dalam menyelesaikan soal fisika dasar.
\end{abstract}

Kata Kunci: Aritmatika, Aljabar, Fisika Dasar

Abstract: Mathematics and physics are closely intertwined because mathematical concepts are used in physics. Physics is a part of science that studies natural behavior through experimental observations and quantitative measurements. Physics uses the language of mathematics to model natural phenomena into mathematical equations, so that in studying physics, mathematical abilities are needed as students' initial abilities in solving physics problems. This study uses a quantitative approach with a descriptive correlation method to analyze the mathematical concepts needed to solve the physical problems of the static electricity material in the Antasari Tadris Physics study program. The results of the study show that there is a high correlation between mastery of arithmetic and algebraic concepts with the ability of students to solve basic physics questions.

Keywords: Arithmetic, Algebraic, Basic Physics

Cara Sitasi: Rahmasari, S. (2019). Penguasaan konsep aljabar dan aritmatika untuk menyelesaikan soal-soal fisika dasar. Math Didactic: Jurnal Pendidikan Matematika, 5(1), 65-74. https://doi.org/10.33654/math.v5i1.521 
Pendidikan tinggi merupakan lembaga yang dituntut untuk mampu mempersiapkan sumber daya manusia (SDM) yang terampil, peka dan kritis dalam menghadapi berbagai tantangan dan perubahan pada masyarakat global. Perkembangan ilmu pengetahuan dan teknologi, perubahan sosial, budaya tuntutan masyarakat dan dunia kerja dalam kehidupan lokal, nasional, maupun, global mengharuskan setiap perguruan tinggi meninjau kembali kualitas dan kualifikasi komptensi lulusannya. (Mikwa, 2018: 331)

Kualitas pendidikan dapat diperoleh dengan kurikulum yang tepat, karena setiap usaha memperbaharui pendidikan, identik dengan memperbaharui kurikulum. Kurikulum Prodi Tadris Fisika adalah seperangkat rencana dan pengaturan mengenai isi, bahan kajian, maupun bahan pelajaran serta cara penyampaiannya dan penilaian yang digunakan sebagai pedoman kegiatan pembelajaran. Kurikulum memuat mata kuliah/bidang kajian strategi yang mendukung pencapaian kompetensi lulusan dan memberikan keleluasaan pada mahasiswa untuk memperluas wawasan dan memperdalam keahlian sesuai dengan minatnya.

Mata kuliah Fisika dasar merupakan mata kuliah wajib yang harus ada di dalam sajian kurikulum Tadris Fisika untuk memperoleh lulusan yang mempunyai pengetahuan dan cakap dalam bidang fisika. Mata kuliah ini harus diprogramkan oleh seluruh mahasiswa Program Studi Tadris Fisika UIN Antasari. Mata kuliah ini mengkaji tentang konsep/prinsip dasar pada bidang fisika. Fisika adalah salah ilmu dalam rumpun IPA. Sebagian besar orang memandang IPA sebagai kumpulan informasi ilmiah, sedangkan para ilmuwan memandang IPA sebagai sebuah cara (metode) untuk menguji dugaan (hipotesis), dan para ahli filsafat memandang IPA sebagai cara bertanya tentang kebenaran dari segala sesuatu yang diketahui.

Sebagai sebuah metode untuk menguji hipotesis, fisika dapat mengembangkan kemampuan berpikir analitis induktif dan deduktif dalam menyelesaikan masalah yang berkaitan dengan peristiwa alam sekitar, baik secara kualitatif maupun kuantitatif dengan menggunakan matematika, serta dapat mengembangkan pengetahuan, keterampilan, dan sikap percaya diri (Depdiknas, 2003: 6).

Menurut Mundilarto (2010: 4) fisika sebagai ilmu dasar memiliki karakteristik yang mencakup bangun ilmu yang terdiri atas fakta, konsep, prinsip, hukum, postulat, dan teori serta metodologi keilmuan. Fisika adalah ilmu yang terbentuk melalui prosedur baku atau biasa disebut sebagai metode ilmiah.

Sebagai salah satu cabang sains, salah satu karakteristik fisika adalah kuantitatif. Pada dasarnya semua konsep fisika selalu dapat dinyatakan dalam bentuk angka. Dengan karakteristik ini, pembahasan fisika selalu dikaitkan dengan masalah pengukuran. Dari pengukuran ini dapat diperoleh data yang selanjutnya dianalisis untuk menjelaskan hubungan antarkonsep. Untuk menjelaskan konsep fisika, matematika memegang peranan yang sangat penting. Rumusan matematis akan memberikan kesederhanaan dalam memerikan konsep maupun memudahkan dalam memahami gejala fisika. Matematika merupakan alat yang paling ampuh untuk menjelaskan gejala fisika (Ruwanto, 2009).

Fisika menggunakan bahasa matematika untuk memodelkan gejala alam yang telah diuji kebenarannya ke dalam persamaan matematis. Oleh karena itu, hal yang paling penting yang harus dikuasai jika ingin belajar fisika adalah penguasaan matematika yang baik. Ini mutlak diperlukan jika seseorang 
ingin menjadi Fisikawan. Seorang fisikawan harus terbiasa dengan konsep-konsep yang ada dalam matematika, karena banyak hal tentang Fisika yang membutuhkan penguasaan matematika dengan baik. Matematika dan fisika memiliki hubungan yang erat, hubungan antara keduanya yaitu (1) metode matematika digunakan dalam fisika dan (2) konsep, pendapat dan cara berfikir fisika digunakan dalam matematika. Sehingga, hubungan antara fisika dan matematika tidak boleh diabaikan dalam disiplin ilmu (Tzanakis, 2002).

Matematika memegang peranan utama dalam fisika, selain kemampuannya untuk memecahkan permasalahan fisika yang paling sederhana sampai bentuk yang paling rumit, matematika sangat membantu penalaran seseorang menelusuri liku-liku fisika yang ternyata tidak mudah. James dan James (Erman Suherman, 2001), mengatakan bahwa matematika adalah ilmu tentang logika mengenai bentuk, susunan, besaran, konsepkonsep yang berhubungan satu dengan yang lainnya dengan jumlah yang banyak yang terbagi ke dalam tiga bidang, yaitu aljabar, analisis, dan geometri. Dalam mempelajari fisika dasar mahasiswa harus mempunyai pengetahuan yang cukup mengenai beberapa konsep matematika yaitu: aljabar, trigonometri, geometri dan kalkulus.

Materi listrik statis berhubungan dengan gejala kelistrikan yang diam atau tidak mengalir. Di dalam meteri listrik statis mahasiswa diharapkan mampu memahami dan menerapkan konsep dan prinsip dasar listrik statis untuk memecahkan persoalan sederhana tentang gejala kelistrikan. Konsep matematika yang harus dimiliki oleh mahasiswa agar mampu menyelesaikan persoalan tentang gejala kelistrikan ini yaitu: aljabar dan aritmatika. Aljabar merupakan cabang matematika yang berhubungan dengan kajian kuantitas, hubungan, dan struktur yang terbentuk. Pada awalnya, kajian dasar dilakukan dengan penyajian simbolik kuantitas serta operasi-operasinya, meliputi persamaan, persamaan linear, persamaan kuadrat. Aritmatika merupakan cabang matematika yang berhubungan dengan operasi dasar bilangan yaitu penambahan, pengurangan, perkalian, pembagian dan ekstraksi akar bilangan real. Konsep listrik statis yang dijabarkan ke dalam persamaan matematis dalam penyelesaiannya sangat berhubungan dengan konsep aljabar dan aritmatika.

Penjelasan mengenai keterkaiatan aljabar dan aritmatika dalam materi listrik statis ini semakin memperkuat keterkaitan konsep matematika dengan fisika. Matematika dan Fisika selalu terjalin erat. Matematika dan Fisika jauh lebih dekat satu sama lain daripada yang biasanya diperkirakan. Metode yang ada di dalam matematika digunakan dalam Fisika. Artinya, Matematika bukan hanya sebagai "bahasa" dari Fisika (yaitu alat untuk mengekspresikan, menangani dan mengembangkan konsep dan teori fisik yang logis), tetapi juga, seringkali menentukan isi dan makna konsep dan teori fisik.

Berdasarkan uraian di atas, peneliti melakukan penelitian yang bertujuan untuk mengetahui penguasaan konsep aljabar dan aritmatika untuk menyelesaikan soal-soal fisika dasar pada materi listrik statis. Sejalan dengan itu maka ada beberapa hasil penelitian relevan yang dilakukan oleh peneliti lain sebagai kajian empiris untuk mendukung korelasi matematika dan fisika, yaitu: (1) Wiladatika (2017), mengenai Hubungan Keterampilan Matematika dengan Kemampuan Menyelesaikan Soal Materi Gaya Pada Siswa SMP Mujahidin Pontianak, menyimpulkan bahwa terdapat hubungan 
antara keterampilan matematika dengan kemampuan menyelesaikan soal materi gaya; (2) Nurlailiyah (2015), mengenai Studi Korelasi Antara Kemampuan Matematika Dengan Hasil Belajar Fisika di SMA PGRI Sumberrejo Bojonegoro Tahun Ajaran 2014/2015, bahwa terdapat korelasi positif antara kemampuan matematika dengan hasil belajar peserta didik pada peserta didik dan (3) Zairi (2017) Hubungan Antara Kemampuan Matematika dengan Kemampuan Menyelesaikan Soal Fisika Pada Materi Gerak Parabola, dari hasil penelitian diperoleh bahwa terdapat hubungan yang positif antara kemampuan matematika dan kemampuan menyelesaikan soal fisika dengan koefisien korelasi sebesar 0,55. Implikasinya, dalam pembelajaran fisika perlu dipertimbangkan kemampuan matematika para siswa.

\section{Metode Penelitian}

Penelitian ini merupakan penelitian kuantitatif, yaitu proses menemukan pengetahuan yang menggunakan data berupa angka sebagai alat menganalisis keterangan mengenai apa yang ingin diketahui (Kasiram, 2008: 149). Populasi dari penelitian ini adalah semua mahasiswa Program Studi Tadris Fisika Semester II dan III Tahun Ajaran 2018/2019. Terdiri dari 34 orang mahasiswa.

Pengambilan sampel dilakukan menggunakan teknik random sampling dengan mengambil secara acak $80 \%$ dari jumlah mahasiswa. Teknik pengambilan data dalam penelitian ini adalah dengan penggalian melalui dokumentasi, yaitu pengetahuan konsep aljabar dan aritmatika (sebagai variabel bebas atau manipulasi) dan kemampuan menyelesaiakan soal fisika dasar materi listrik statis, pada mahasiswa semester II dan III (sebagai variabel terikat atau respon) pada laporan nilai akhir mahasiswa atau akumulasi nilai semester II dan III tahun ajaran 2018/2019. Variabel kontrol dalam penelitian ini adalah jumlah jam mata kuliah matematika dan fisika.

Data dianalisis dengan menggunakan uji korelasi. Korelasi menunjukkan besarnya hubungan antara variabel bebas dengan variabel terikat. Besarnya hubungan dinyatakan dengan koefisien korelasi. Harga koefisien korelasi dari $-1 \mathrm{~s} / \mathrm{d}+1$. Harga +1 menunjukan hubungan positif sempurna. Harga 0 menunjukan tidak ada hubungan. Koefisien korelasi ditentukan dengan menggunakan rumus berikut:

$$
r=\frac{n \cdot \sum x y-\left(\sum x\right)\left(\sum y\right)}{\left.\left.\sqrt{n \cdot \sum x^{2}}\left(\sum x\right)^{2}\right)\left(n \cdot \sum y^{2}-\sum y\right)^{2}\right)}
$$

dimana,

$\mathrm{r} \quad=$ koefisien korelasi

$\mathrm{n} \quad=$ besarnya sampel

$\sum \mathrm{x} \quad=$ jumlah nilai $\mathrm{x}$

$\sum \mathrm{y} \quad=$ jumlah nilai $\mathrm{y}$

$\sum \mathrm{x}^{2}=$ jumlah nilai kuadrat dari $\mathrm{x}$

$\sum \mathrm{y}^{2}=$ jumlah nilai kuadrat dari $\mathrm{y}$

$\sum \mathrm{xy}=$ jumlah produk nilai $\mathrm{x}$ dan $\mathrm{y}$

Untuk memberikan tafsiran pada nilai koefisien korelasi, dapat digunakan patokan sebagai berikut:

Tabel 1. Tafsiran Koefisien Korelasi

\begin{tabular}{|c|c|c|}
\hline Positif & Negatif & Penafsiran \\
\hline $0.90-1.00$ & $-0.90--1.00$ & $\begin{array}{c}\text { Korelasi } \\
\text { sangat tinggi } \\
\text { (very high) }\end{array}$ \\
\hline $0.70-0.90$ & $-0.70--0.90$ & $\begin{array}{c}\text { Korelasi } \\
\text { tinggi (high) }\end{array}$ \\
\hline $0.50-0.70$ & $-0.50--0.70$ & $\begin{array}{c}\text { Korelasi } \\
\text { sedang } \\
\text { (moderate) }\end{array}$ \\
\hline $0.30-0.50$ & $-0.30--0.50$ & $\begin{array}{c}\text { Korelasi } \\
\text { rendah (low) }\end{array}$ \\
\hline
\end{tabular}




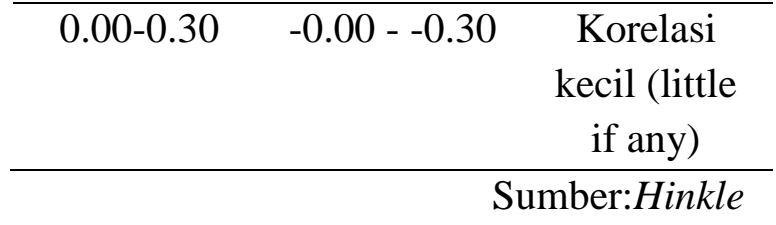

Sedangkan korelasi dari pengetahuan konsep aljabar dan aritmatika dengan kemampuan menyesaikan soal fisika dasar materi listrik statis dapat dianalisis dengan menggunakan persamaan. Selain dilakukan uji korelasi, juga dilakukan uji keberartian dari koefisien korelasi yang telah diperoleh untuk mengetahui keberlakuan koefisien korelasi tersebut dengan menggunakan uji-t untuk menguji hipotesis adanya korelasi yang tidak sama dengan nol atau signifikan (Ha) atau korelasi sama dengan nol atau tidak ada hubungan antara kedua variabel.

Koefisien korelasi diuji keberartiannya dengan menggunakan dengan uji-t, sehingga:

$$
t=\frac{r \sqrt{n-2}}{\sqrt{1-r^{2}}}
$$

dengan, $\mathrm{r}=$ koefisien korelasi dan $\mathrm{n}=$ jumlah data Hipotesis yang diuji adalah:

Ho: koefisien korelasi pengetahuan konsep aljabar dan aritmatika dengan kemampuan menyelesaikan soal fisika dasar materi listrik statis sama dengan nol

Ha: koefisien korelasi pengetahuan konsep aljabar dan aritmatika dengan kemampuan menyelesaikan soal fisika dasar materi listrik statis tidak sama dengan nol, atau signifikan.

Kriteria pengujiannya yaitu Ho ditolak jika nilai thitung lebih besar dari $t_{\text {tabel }}$ dengan derajat kebebasan $(\mathrm{db} / \mathrm{df})=\mathrm{n}-2$, dan demikian pula sebaliknya.

\section{Hasil}

\section{Hasil dan Pembahasan}

Aljabar dan Aritmatika dengan Kemampuan

Menyelesaikan Soal Fisika dasar Materi

Listrik Statis Mahasiswa III

\begin{tabular}{lcc}
\hline & Matematika & Fisika \\
\hline Mean & 76,94 & 78,99 \\
Median & 74,00 & 78,85 \\
Modus & 80,70 & 81,00 \\
Varians & 34,56 & 34,74 \\
Nilai Min & 70,00 & 70,00 \\
Nilai Max & 88,00 & 90,10 \\
\hline
\end{tabular}

Jika kedua data tingkat mahasiswa yang sudah diperoleh diatas digabungkan, maka akan diperoleh data sebagai berikut:

Tabel 4. Skor Rata-Rata Pengetahuan Konsep Aljabar dan Aritmatika dengan Kemampuan Menyelesaikan Soal Fisika dasar Materi Listrik Statis Mahasiswa Mahasiswa Semeseter II dan III

\begin{tabular}{lcc}
\hline & Matematika & Fisika \\
\hline Mean & 76,1 & 77,8 \\
Median & 74,7 & 78,0 \\
Modus & 73,0 & 79,0 \\
Varians & 22,3 & 23,3 \\
Nilai Min & 70,0 & 70,0 \\
\hline
\end{tabular}




\begin{tabular}{lll}
\hline Nilai Max & 88,0 & 90,1 \\
\hline
\end{tabular}

Berdasarkan data yang diperoleh, dapat diketahui bahwa rata-rata pengetahuan konsep aljabar dan aritmatika lebih kecil daripada ratarata kemampuan menyesaikan soal fisika dasar. Adapun hasil perhitungan dengan menggunakan persamaan (1) dan (2) diperoleh nilai koefisien korelasi ( $r$ ), $t_{\text {hitung }}$ dan $t_{\text {tabel }}$ untuk masing-masing kelas dan keseluruhan yaitu sebagai berikut:

Tabel 5. Nilai Koefisien Korelasi, $t_{\text {hitung }}$ dan $t_{\text {tabel }}$ Tiap Tingkat Semester Mahasiswa

\begin{tabular}{cccc}
\hline Semester & $\mathbf{r}$ & thitung & ttabel \\
\hline II & 0,75 & 4,25 & 2,14 \\
III & 0,77 & 4,82 & 2,12 \\
Gabungan & 0,82 & 8,14 & 2,04 \\
\hline
\end{tabular}

Dari tabel di atas, diperoleh nilai koefisien korelasi (r) sebesar 0,75 untuk mahasiswa semester II. Nilai koefisien tersebut menunjukkan bahwa antara pengetahuan konsep aljabar dan aritmatika sebagai variabel manipulasi mempunyai hubungan positif dan tinggi dengan kemampuan menyesaikan soal fisika dasar materi listrik statis. Sebagai variabel responnya, jika koefisien korelasi mendekati 1, dapat diartikan hubungan antara variabel $x$ dan y erat dan perubahannya searah. Artinya, jika variabel x bertambah besar maka variabel y juga akan bertambah besar. Dengan kata lain, jika penguasaan konsep matematika mahasiswa baik maka kemampuan menyelesaikan soal fisika dasar pun akan baik.

Untuk semester III diperoleh data dengan menggunakan analisis yang sama dengan mahasiswa semester II, diperoleh nilai koefisien korelasi yaitu $r=0.77$ yang artinya, sama seperti pada semester II, pada semester III diperoleh nilai koefisien korelasi mendekati 1. Dengan kata lain, pada semester III juga terdapat hubungan positif dan tinggi antara penguasaan konsep aljabar dan aritmatika peserta didik dengan kemampuan menyelesaikan soal fisika dasar.

Sesuai dengan tabel 1, dapat ditafsirkan bahwa dari data yang diperoleh mempunyai korelasi tinggi (high) atau dapat diartikan bahwa korelasi dari kedua variabel dikatakan signifikan berdasarkan uji-t.

Hasil penelitian menunjukkan bahwa ada pengaruh yang signifikan antara penguasaan konsep aljabar dan aritmatika terhadap kemampuan menyelesaikan soal fisika dasar. Secara individual pengetahuan konsep matematika memberikan pengaruh yang signifikan terhadap kemampuan menyelesaikan soal fisika dasar. Matematika sangat dibutuhkan dalam menyelesaikan persoalan-persoalan dalam fisika. Jadi, pada dasarnya seseorang yang memiliki pengetahuan konsep matematika akan dengan mudah memahami konsep fisika dan menyelesaikan soal-soal perhitungan fisika.

\section{Pembahasan}

Fisika adalah bagian dari ilmu sains yang mempelajari perilaku alam melalui pengamatan secara eksperimental dan pegukuran secara kuantitatif. Fisika menggunakan bahasa matematika untuk memodelkan gejala alam ke dalam persamaan matematis. Sehingga di dalam mempelajari Fisika, diperlukan kemampuan matematis sebagai kemampuan awal peserta didik dalam menyelesaikan permasalahan Fisika.

Hubungan yang tinggi antara matematika dan fisika terlihat pada hasil analisis data yang menunjukkan bahwa ada pengaruh yang tinggi antara penguasaan konsep aljabar dan aritmatika terhadap kemampuan menyelesaikan soal fisika dasar mahasiswa semester II dan III program studi 
Tadris Fisika UIN Antasari tahun akademik 2018/2019. Secara individual pengetahuan konsep matematika memberikan pengaruh yang signifikan terhadap kemampuan menyelesaikan soal fisika dasar.

Penguasaan konsep matematika dalam mengerjakan soal fisika dasar pada materi listrik statis dapat dilihat pada tabel di bawah ini:

Tabel 6. Hubungan Aljabar dan Aritmatika pada Kemampuan menyelesaikan Soal Listrik Statis

\begin{tabular}{|c|c|c|}
\hline Jenis Soal & $\begin{array}{l}\text { Persamaan Matematis } \\
\text { yang digunakan dalam } \\
\text { penyelsaian soal }\end{array}$ & $\begin{array}{c}\text { Jenis } \\
\text { Konsep } \\
\text { Matematika }\end{array}$ \\
\hline $\begin{array}{l}\text { Gaya listrik } \\
\text { pada elektron } \\
\text { dan proton }\end{array}$ & $F=\frac{1}{4 \pi \varepsilon_{o}} \frac{Q_{1} Q_{2}}{r^{2}}$ & $\begin{array}{l}\text { Aljabar dan } \\
\text { aritmatika }\end{array}$ \\
\hline $\begin{array}{l}\text { Muatan yang } \\
\text { memberikan } \\
\text { gaya yang } \\
\text { lebih besar }\end{array}$ & $F_{12}=k \frac{Q_{1} Q_{2}}{l^{2}}$ & $\begin{array}{l}\text { Aljabar dan } \\
\text { aritmatika }\end{array}$ \\
\hline $\begin{array}{lr}\text { Tiga } & \text { Muatan } \\
\text { pada } & \text { satu } \\
\text { garis } & \end{array}$ & $\begin{array}{l}F_{31}=\frac{1}{4 \pi \varepsilon_{o}} \frac{Q_{1} Q_{2}}{r^{2}} \\
F_{32}=1 \frac{Q_{1} Q_{2}}{2}\end{array}$ & $\begin{array}{l}\text { Aljabar dan } \\
\text { aritmatika }\end{array}$ \\
\hline $\begin{array}{l}\text { Gaya listrik } \\
\text { dengan } \\
\text { menggunakan } \\
\text { komponen- } \\
\text { komponen } \\
\text { vektor }\end{array}$ & $\begin{array}{c}F=-F_{32}+F_{31} \\
F_{31}=\frac{1}{4 \pi \varepsilon_{o}} \frac{Q_{1} Q_{2}}{r^{2}} \\
F_{32}=\frac{1}{4 \pi \varepsilon_{o}} \frac{Q_{1} Q_{2}}{r^{2}} \\
F_{31 x}=F_{31} \cos \theta \\
F_{31 y}=-F_{31} \sin \theta \\
F_{x}=F_{31 x} \\
F_{y}=F_{32}+F_{31 y}\end{array}$ & $\begin{array}{l}\text { Aljabar, } \\
\text { aritmatika } \\
\text { dan } \\
\text { trogonometri }\end{array}$ \\
\hline & $F=\sqrt{F_{x}^{2}+F_{y}^{2}}$ & \\
\hline $\begin{array}{l}\text { Medan listrik } \\
\text { satu muatan } \\
\text { Medan listrik } \\
\text { diantara dua } \\
\text { muatan titik }\end{array}$ & $\begin{array}{c}E=k \frac{Q}{r^{2}} \\
E=k \frac{Q_{1}}{r_{1}^{2}}+k \frac{Q_{2}}{r_{2}^{2}} \\
E=k\left(\frac{Q_{1}}{r_{1}^{2}}+\frac{Q_{2}}{r_{2}^{2}}\right)\end{array}$ & $\begin{array}{l}\text { Aljabar dan } \\
\text { aritmatika } \\
\text { Aljabar dan } \\
\text { aritmatika }\end{array}$ \\
\hline $\begin{array}{l}\text { Medan } \\
\text { Listrik di } \\
\text { bawah dua } \\
\text { muatan titik }\end{array}$ & $\begin{array}{l}\text { Titik A } \\
\qquad E_{A 1}=k \frac{Q}{r_{1}^{2}}\end{array}$ & $\begin{array}{l}\text { Aljabar, } \\
\text { aritmatika } \\
\text { dan } \\
\text { trigonometri }\end{array}$ \\
\hline
\end{tabular}

$$
\begin{gathered}
E_{A 2}=k \frac{Q}{r_{2}^{2}} \\
E_{A x}=E_{A 1} \cos \theta \\
E_{A y}=E_{A 2}-E_{A 1} \sin \theta \\
E_{A}=\sqrt{E_{A x}^{2}+E_{A y}^{2}}
\end{gathered}
$$

Titik B

$$
\begin{gathered}
E_{B 1}=E_{B 2}=\frac{k Q}{r^{2}} \\
E_{B}=2 E_{B 1} \cos \theta
\end{gathered}
$$

Konsep matematika yaitu aljabar dan aritmatika memegang peranan yang sangat penting dalam penyelesaian persamaan matematis pada soal listrik statis. Hal ini sangat terlihat jelas pada tabel yang dipaparkan di atas. Dan tak hanya aljabar dan aritmatika ternyata pada saat penyelesaian soal listrik statis konsep trigonometri juga dibutuhkan dalam penyelsaian soal yang berhubungan dengan Gaya listrik dengan menggunakan komponen-komponen vektor dan Medan Listrik di bawah dua muatan titik.

Hal ini juga didukung dari data yang diperoleh. Data pengetahuan konsep matematika dan kemampuan menyelesaikan soal fisika dasar menunjukkan korelasi tinggi (high) atau dapat diartikan bahwa korelasi dikatakan signifikan.

Jadi jelaslah bahwa penguasaan konsep matematika yaitu aljabar dan aritmatika sangat dibutuhkan dalam menyelesaiakan soal fisika dasar dalam penelitian ini pada materi listrik statis. Pada saat penyelsaian soal juga ditemukan bahwa ternyata di dalam menyelesaikan soal listrik statis tak hanya konsep aljabar dan aritmatika tetapi konsep trigonometri juga dibutuhkan. Keterkaitan antara matematika dan fisika sangat jelas terlihat pada hasil penelitian. Fisika tak dapat dipisahkan dari matematika karena metode dalam matematika digunakan dalam fisika. Fisika menggunakan bahasa matematika untuk memodelkan gejala alam ke dalam persamaan matematis. 
Pencapaian kategori korelasi yang tinggi pada mahasiswa yang telah memprogramkan mata kuliah matematika dan menyelesaikan soal listrik statis pada mata kuliah fisika dasar didukung oleh: Penelitian yang dilakukan oleh Rhahim (2015) menyimpulkan bahwa terdapat hubungan antara keterampilan matematika dengan kemampuan menyelesaikan soal fisika pada materi momentum dan impuls. Hubungan keduanya sangat kuat dengan koefisien korelasi sebesar 0,9039. Hasil penelitian yang dilakukan oleh Hasbi (2012) adalah adanya pengaruh kemampuan trigonometri terhadap kemampuan fisika dari mahasiswa program studi pendidikan fisika FKIP UNTAD. Dan hasil penelitian Kereh (2014) yaitu mengindikasikan bahwa materi matematika dasar yang diuji sangat relevan dengan materi perkuliahan pendahuluan fisika inti yang dilakukan.

Fisika memiliki kaitan erat dengan matematika.Matematika mampu menyediakan kerangka logika di mana hukum-hukum fisika dapat diformulasikan secara tepat. Definisi, teori, dan model fisika selalu dinyatakan menggunakan hubungan matematis. Fisika tidak mungkin berjalan tanpa matematika, karena konsep tentang alam ini tidak akan bisa diutarakan dan dimanfaatkan dengan baik tanpa matematika.

Fisika merupakan salah satu cabang ilmu pengetahuan alam yang mempelajari fenomena alam, yang mencakup materi, gerak, serta energi yang menyertainya. Dengan kata lain, fisika adalah suatu ilmu tentang dunia di sekitar kita dan bagaimana segala sesuatu di dalamnya bekerja (Lang, 2009). Fisika berkembang melalui pengamatan eksperimen dan pengukuran kuantitatif dengan tujuan utamanya untuk menemukan hukum-hukum dasar tentang alam. Selanjutnya, hukum- hukum dasar tersebut digunakan dalam pengembangan teori untuk meramalkan hasil eksperimen-eksperimen berikutnya. Hukumhukum dasar dalam teori fisika diekspresikan dalam bahasa matematika. Ini berarti matematika memegang peranan yang sangat penting dalam menjabarkan dan menjelaskan gejala fisika yang makroskopik maupun mikroskopik. Representasi matematis dalam pemerian konsep fisika dapat membantu pebelajar dalam memahami gejala fisika terkait (Halliday et al, 2007). Oleh karena itu, matematika merupakan materi yang esensial untuk dipelajari dalam pendidikan calon pendidik fisika.

\section{SIMPULAN DAN SARAN}

\section{Simpulan}

1. Konsep matematika yang dibutuhkan dalam penyelesaian soal fisika dasar khususnya materi listrik statis yaitu konsep aljabar dan aritmatika.

2. Terdapat korelasi positif dan tinggi yang berlaku pada semua tingkatan antara peguasaan konsep matematika dengan kemampuan menyelesaikan soal fisika dasar pada Mahasiswa semester II dan III program studi tadris fisika tahun akademik 2018/2019.

\section{Saran}

Sehubungan dengan kesimpulan hasil penelitian yang dikemukakan di atas, maka peneliti mengajukan saran-saran sebagai berikut:

1. Hasil penelitian ini hendaknya bisa menjadi suatu pembelajaran bagi mahasiswa yang memprogramkan, mata kuliah fisika dasar agar lebih meningkatkan pengetahuan konsep 
matematika untuk memudahkan dalam menyelesaikan soal fisika dasar.

2. Bagi dosen mata kuliah fisika dasar kiranya dapat melakukan kajian lebih mendalam lagi mengenai integrasi antara matematika dan fisika

\section{DAFTAR PUSTAKA}

Depdiknas. 2003. Standar Kompetensi Mata Pelajaran Fisika Sekolah Menengah Atas dan Madrasah Aliyah. Jakarta: Pusat Kurikulum, Balitbang

Halliday, D., Resnick, R., \& Walker, J. (2007). Fundamentals of Physics 8th Ed. Canada: John Wiley \& Sons Canada.

Hasbi, Muh. (2012). Pengaruh Kemampuan Trigonometri TerhadapKemampuan Fisika Dikaitkan dengan Gaya Kognitif Mahasiswa Program Studi Pendidikan Fisika FKIP Universitas Tadulako. Skripsi Jurusan PMIPA FKIP Universitas Tadulako

Hinkle DE, Wiersma W, dan Jurs SG. 2003. Applied Statistics for the Behavioural Science. London: Boston

Kasiram, Moh. 2008. Metodologi Penelitian. Malang: UIN-Malang Pers.

Kereh, C.T. Liliasari, P. C. Tjiang. Sabandar, J. 2014. Korelasi Penguasaan Materi Matematika Dasar dengan Penguasaan Materi Pendahuluan Fisika Inti. Jurnal Pendidikan Fisika Indonesia, 10(2): 140 - 149.

Lang, H. (2009). Head First Physics. Sebastopol: O'Reilly Media, Inc.
Mikwa UIN Antasari. 2018. Buku Kurikulum Kerangka Kualifikasi Nasional Indonesia. Banjarmasin: UIN Antasari

Mundilarto. (2010). Penilaian Hasil Belajar Fisika. Yogyakarta : P2IS UNY

Nurlailiya, Alfi., Deta, Alan, Utama. (2015). Studi Korelasi Antara Kemampuan Matematika Dengan Hasil Belajar Fisika Di SMA PGRI Sumberrejo Bojonegoro Tahun Ajaran 2014/2015. Jurnal penelitian Fisika dan Aplikasinya 5(2): 64-69.

Rhahim Ervina. (2015). Hubungan Keterampilan Matematika dengan Kemampuan Menyelesaikan Soal Fisika Terhadap Miskonsepsi Siswa Pada Materi Impuls Momentum Di MAN 2 Pontianak. Jurnal Penelitian. FKIP UNTAN

Ruwanto, Bambang. 2009. Gagasan Mengajarkan Fisika Matematik di SMA. Yogyakarta: Seminar Nasional Penelitian, Pendidikan, dan Penerapan MIPA di FMIPA Universitas Negeri Yogyakarta

Suherman. E. 2001. Pembelajaran Matematika Kontemporer. Bandung: JICA

Tzanakis, C. 2002. On The Relation Between Mathematics and Physics in Undergraduate Teaching. 2nd International Conference on the Teaching of Mathematics (at the undergraduate level): 387 .. 
Wiladatika, L., S.S. Sitompul, \& D. Mahmuda. 2017. Hubungan Keterampilan Matematika dengan Kemampuan Menyelesaikan Soal Materi Gaya pada Siswa SMP Mujahidin Pontianak. Jurnal Pendidikan dan Pembelajaran, 6(1): 19.

Zairi, Alfi. Sutrisno, Leo. S, Haratua Tiur Maria. 2017. Hubungan Antara Kemampuan Matematika dengan Kemampuan Menyelesaikan Soal Fisika Pada Materi Gerak Parabola. Jurnal Ilmiah Universitas Tanjungpura. 